\title{
THE EFFECT OF PRODUCTION ROOM LAYOUT AND PRODUCTION MACHINE MAINTENANCE ON PRODUCTION EFFECTIVENESS
}

\author{
Muhammad Herdiansyah \\ Universitas Langlangbuana, Indonesia \\ muhammadherdi28@gmail.com
}

\begin{abstract}
The intense business competition in the industrial world requires companies to always advance. Many ways did so that companies can more effective in all fields so that company productivity can increase. In relation, the Production Room Layout and Production Machine Maintenance are very influential in the creation of effectiveness in the production activities. This study aims to examine the effect of Production Room Layout and Machine Maintenance on Production Effectiveness at PT. Bintang Usaha Nasional. The population in this study is the number of employees in the production field of PT. Bintang Usaha Nasional as many as 30 people. Data collection techniques used were observation, interviews, questionnaires, and literature study. The statistical analysis method used is Path Analysis with partial hypothesis testing (t-test) and simultaneous ( $f$ test). The results of the research show that all independent variables (Production Room Layout and Machine Maintenance) have a significant effect on the effectiveness of production at PT. Bintang Usaha Nasional. The Effect of Production Room Layout and Machine Maintenance on Production Effectiveness is $85.7 \%$, while the remaining $14.3 \%$ comes from other variables besides the production room layout and machine maintenance.
\end{abstract}

Keywords: Production Room Layout, Production Machine Maintenance, Production Effectiveness

\section{INTRODUCTION}

In this globalization era, the rapid advancement of the technology world accompanied by intense business competition in the industrial world requires companies to always develop and innovate in various fields. Many ways can be done so that the company can continue to survive to face competition, but everything will return to a fundamental goal, namely how to make the company more effective and efficient in all fields so that company productivity can increase.

Effectiveness is the most harmonious comparison between the work done and the results obtained in terms of the time spent, the funds spent, and the place used. According to Priansa (2015) that effectiveness is the achievement of businesses following the plan (doing the right thing) or the planned results compared with the realization of the results. According to Ravianto (2014) Effectiveness is how well the work is done, the extent to which people produce outputs as expected. This means that if a job can be completed following planning, both in time, cost, and quality it can be said to be effective. Things that can affect the creation of production effectiveness include the layout of the production space. This layout planning can greatly affect the effectiveness of production and is an important aspect both in the long term and short term.

The layout design will determine how the activities of the production machine can be arranged following the needs to support a good layout planning of the production machine will be able to increase the use of space, time or output produced. On the other hand, the layout of production machinery that cannot be set in the length of the distance of material transfer can have an impact on the time of the production process, as well as transportation costs related to fuel. In effect on production activities. 
The procedure of contributing to the participation of production, as quoted by Rusdiana (2014) that the Layout (Layout) is a way of placing production facilities to facilitate an effective and efficient production process. This is supported by research conducted previously by Laksanawati (2016) in a PT. GGS. According to him the placement and identification of materials must be completed and equipped to help the operators to work more effectively and obtain maximum results because of the material structuring procedures listed at PT. GGS Requesting is not appropriate, causing inefficient time and work to be ineffective for starting and storing materials and makes it difficult for operators to manage and manage materials with both stock and data. Not only does layout affect the effectiveness, but maintenance also affects effectiveness. According to Assauri (2016) that with the maintenance of the machine, the effectiveness of production will be maintained. If the machines used in the production process are not properly maintained and maintained, there will be damage to the machine and cause disruption and obstacles to the production process and product performance. According to Anggraini (2016) who researched the company PT. Nikomas Gemilang concluded that machine maintenance proved to have a positive and significant effect on the quality of shoes because by taking into account the state of the machine by holding maintenance can support production results that are produced with good quality and by suppressing machine maintenance, the company has minimized the deviation of absorption of raw material costs because the production of shoes produced is of good quality and minimizes defects due to constraints in production. The quality of shoes here is very closely related to the effectiveness of production

In relation, the layout, as well as machine maintenance, greatly influences the creation of effectiveness in production activities. According to Handoko (2014) that maintenance/maintenance of the machine in addition to influencing the quality of the product also affects the age of the machine. The layout of the machine must provide sufficient space for engine maintenance. Therefore, planning must consider the characteristics of the work carried out by the machine concerned and the size or shape of the equipment needed in engine maintenance.

PT. Bintang Usaha Nasional which is located on Jl. Cipaku No. 107, Bandung, West Java is a textile company with fabric business products (Makloon). The effectiveness of production at this company often experiences fluctuations, due to the lack of suitability of production planning both in terms of time and quality. This can be seen in terms of production quantity and quality of production. One of the reasons is due to the layout of the production space because the order of the production layout is not following the flow of material, so time is not utilized properly. In the context of poor machine maintenance, the machine is damaged or stopped in the production process so that the goods suffer damage or defects. Not only that, but damage to production machinery also results in the cessation of production activities, so that targets and quality are sometimes difficult to achieve.

Effectiveness of production at PT. Bintang Usaha Nasional is hampered due to the lack of orderly layout arrangements which results in the production process activities which are felt by employees to be lacking in terms of comfort and irregular sequence of machines which results in the far transfer of material one to the next process so that the lack of effectiveness of time and production processes is less effective. Besides, the lack of optimal maintenance which causes the machine to stop suddenly (damaged) so that the production delays that result in additional production time, production 
costs so that the production process becomes less effective.

Based on the previous discussion, further research will be carried out to test the Effect of Layout of Production Room and Machine Maintenance on Production Effectiveness in PT. Bintang Usaha Nasional.

\section{METHODS}

This research was conducted to understand the layout of the production space and machinery for production assistance at PT. Bintang Usaha Nasional, using Sugiarto (2017) research design namely: (1) Descriptive Research is a study that describes a certain characteristic or characteristic of a phenomenon for various problems that occur. (2) Verification Research is a method that discusses theories with hypotheses using calculations with research methods while the research method used is a survey method that is research that takes samples from research using questionnaires as data collection tools.

The location of this research was conducted at PT. Bintang Usaha Nasional, Jln. Cipaku No. 107, Bandung, West Java, which provides information about company data specifically in the field of operations. In this research, the participant is a production company at PT. Bintang Usaha Nasional with a total of 30 people.

\section{RESULTS AND DISCUSSION Descriptive Analysis}

The measurement used in this study is the Likert scale. Skert Likert uses interval scale with successive categories from "strongly agree" to "strongly disagree" To find out the responses of respondents about the Layout of Production Room as a whole, it can be seen from the recapitulation of respondents' responses, as follows: 
Table 1. Respondents' responses regarding the Production Room Layout

\begin{tabular}{|c|c|c|c|c|c|c|c|c|c|c|}
\hline Statement & $\begin{array}{l}\text { Alte } \\
\text { SA }\end{array}$ & A & $\begin{array}{l}\text { ive A } \\
\text { QA }\end{array}$ & $\begin{array}{l}\text { Answ } \\
\text { D }\end{array}$ & & $\begin{array}{l}\text { Current } \\
\text { score }\end{array}$ & $\begin{array}{l}\text { t Ideal } \\
\text { Score }\end{array}$ & $\%$ & Average & Category \\
\hline $\begin{array}{l}\text { The results and quality of } \\
\text { products produced are } \\
\text { following the target }\end{array}$ & 3 & 22 & 5 & 0 & 0 & 118 & 150 & 78,67 & 3,93 & Agree \\
\hline $\begin{array}{l}\text { The production layout is } \\
\text { correct }\end{array}$ & 4 & 9 & 12 & 5 & 0 & 102 & 150 & 68 & 3,4 & $\begin{array}{l}\text { Quite } \\
\text { Agree }\end{array}$ \\
\hline $\begin{array}{l}\text { The factory room is spacious } \\
\text { enough to guarantee the } \\
\text { comfort of the production } \\
\text { process }\end{array}$ & 6 & 9 & 13 & 2 & 0 & 109 & 150 & 72,67 & 3,63 & Agree \\
\hline $\begin{array}{l}\text { The floor is solid so it can } \\
\text { accommodate the weight of } \\
\text { the heavy machine }\end{array}$ & 3 & 10 & 10 & 7 & 0 & 99 & 150 & 66 & 3,3 & $\begin{array}{l}\text { Quite } \\
\text { Agree }\end{array}$ \\
\hline $\begin{array}{l}\text { Machine maintenance } \\
\text { activities are easy to do }\end{array}$ & 3 & 10 & 16 & 0 & 1 & 104 & 150 & 69,33 & 3,47 & Agree \\
\hline $\begin{array}{l}\text { Machine replacement } \\
\text { activities are easy to do }\end{array}$ & 2 & 16 & 8 & 4 & 0 & 106 & 150 & 70,67 & 3,53 & Agree \\
\hline $\begin{array}{l}\text { The layout of the machine is } \\
\text { following the order of } \\
\text { production }\end{array}$ & 0 & 4 & 6 & 18 & 2 & 72 & 150 & 48 & 2,4 & Disagree \\
\hline $\begin{array}{l}\text { A slight displacement due to } \\
\text { the layout of the production } \\
\text { machine is well organized }\end{array}$ & 0 & 16 & 8 & 2 & 0 & 92 & 150 & 61,33 & 3,07 & $\begin{array}{l}\text { Quite } \\
\text { Agree }\end{array}$ \\
\hline $\begin{array}{l}\text { Production flow is following the } \\
\text { order of production }\end{array}$ & 2 & 16 & 9 & 2 & 1 & 106 & 150 & 70,67 & 3,53 & Agree \\
\hline $\begin{array}{l}\text { The workplace is large enough } \\
\text { so that it does not interfere } \\
\text { with the safety and smooth } \\
\text { production }\end{array}$ & 4 & 13 & 12 & 1 & 0 & 110 & 150 & 73,33 & 3,67 & Agree \\
\hline $\begin{array}{l}\text { Availability of rest areas, } \\
\text { parking lots, toilets, and so on } \\
\text { in the work area }\end{array}$ & 2 & 13 & 11 & 3 & 1 & 102 & 150 & 68 & 3,4 & $\begin{array}{l}\text { Quite } \\
\text { Agree }\end{array}$ \\
\hline $\begin{array}{l}\text { Availability of storage of goods } \\
\text { while waiting for the production } \\
\text { process }\end{array}$ & 6 & 11 & 9 & 1 & 3 & 106 & 150 & 70,67 & 3,53 & Agree \\
\hline $\begin{array}{r}\text { TOTAL } \\
\end{array}$ & 35 & 149 & 119 & 45 & 8 & 1226 & 1800 & 817,34 & 40,86 & \\
\hline
\end{tabular}

Information:

SA = Strongly Agree

$A=$ Agree

QA = Quite Agree

$\mathrm{D}=$ Disagree

$\mathrm{SD}=$ Strongly Disagree

Actual Score $=$ Statement weight $\mathrm{x}$ Number of respondents

Ideal Score $=$ Number of respondents $x \quad$ Number of Responses statement

Average = Actual score: Amount respondent
Percentage = Actual score: ideal score $x 100$

Overall from table 1 , a total score of 1226 is obtained from the ideal score of 1800 so that the percentage value of $68,11 \%$ can be obtained from measurements as follows:

Maximum Index Value

$=5 \times 12 \times 30=1800$

Minimum Index Value

$=1 \times 12 \times 30=360$

Interval Distance $=(\max$ value $-\min$ value $): 5=(1800-360): 5=288$ 
Percentage of score $=[($ total score $): \max$ value] $\times 100 \%$

$=(1226: 1800) \times 100 \%$

$=68,11 \%$

The percentage value obtained at $68.11 \%$ refers to the assessment criteria included in the agreed category, so it can be seen that the Layout of the
Production Room at PT. Bintang Usaha Nasional are considered good.

In the process of knowing the responses of respondents about Machine Maintenance as a whole, it can be seen from the results of the recapitulation of responses in the following table 2:

Table 2. Respondents' responses to Production Machine Maintenance

\begin{tabular}{|c|c|c|c|c|c|c|c|c|c|c|}
\hline Statement & Alte & nat & ve A & now & & $\begin{array}{c}\text { Curren } \\
\text { score }\end{array}$ & $\begin{array}{l}\text { Ideal } \\
\text { Score }\end{array}$ & $\%$ & Average & Category \\
\hline & SA & $A$ & QA & $D$ & SD & & & & & \\
\hline Routine Engine Inspection & 1 & 22 & 3 & 2 & 2 & 108 & 150 & 72 & 3,6 & Agree \\
\hline Engine maintenance & 4 & 22 & 3 & 1 & 0 & 119 & 150 & 79,33 & 3,97 & Agree \\
\hline $\begin{array}{l}\text { Carry out activities in } \\
\text { maintaining facilities of } \\
\text { equipment in good condition. }\end{array}$ & 2 & 17 & 7 & 4 & 0 & 107 & 150 & 71,33 & 3,57 & Agree \\
\hline $\begin{array}{l}\text { The existence of maintenance } \\
\text { directly after experiencing } \\
\text { damage }\end{array}$ & 0 & 1 & 19 & 5 & 5 & 76 & 150 & 50,67 & 2,53 & Disagree \\
\hline The rate of improvement is & 1 & 19 & 6 & 2 & 2 & 105 & 150 & 70 & 3,5 & Agree \\
\hline TOTAL & 8 & 81 & 38 & 14 & 9 & 515 & 750 & 343,33 & 17,17 & \\
\hline
\end{tabular}

Overall in table 2, a total score of 515 can be obtained from the ideal score of 750 , so that a percentage value of $68.67 \%$ is obtained, obtained from measurements as follows:

Maximum Index Value

$=5 \times 5 \times 30=750$

Minimum Index Value

$=1 \times 5 \times 30=150$

Interval Distance $=(\max$ value $-\min$ value): 5

$=(750-150): 5=120$

Percentage of score $=[($ total score $): \max$ value] $\times 100 \%$

$$
=(515: 750) \times 100 \%=68.67 \%
$$

The percentage value obtained is $68.67 \%$ if it refers to the assessment criteria included in the agreed category, so it can be seen that the maintenance of the machines used at PT. Bintang Usaha Nasional is considered good.

Furthermore, to be able to know the response of respondents regarding the overall effectiveness of production can be seen in the results of the respondent's recapitulation, as follows: 
Tabel 3. Respondents' responses to Production effectiveness

\begin{tabular}{|c|c|c|c|c|c|c|c|c|c|c|}
\hline Statement & Alte & rnati & ive A & Insv & vers & $\begin{array}{l}\text { Curren } \\
\text { score }\end{array}$ & $\begin{array}{l}\text { Ideal } \\
\text { Score }\end{array}$ & $\%$ & Average & Category \\
\hline & SA & $A$ & QA & $\mathrm{D}$ & SD & & & & & \\
\hline $\begin{array}{l}\text { Achievement of the production } \\
\text { following the targets set }\end{array}$ & 1 & 22 & 3 & 2 & 2 & 108 & 150 & 72 & 3,6 & Agree \\
\hline $\begin{array}{l}\text { Defective products can be } \\
\text { minimized properly }\end{array}$ & 4 & 22 & 3 & 1 & 0 & 119 & 150 & 79,33 & 3,97 & Agree \\
\hline $\begin{array}{l}\text { The resulting product } \\
\text { following the standards }\end{array}$ & 2 & 20 & 7 & 1 & 0 & 113 & 150 & 75,33 & 3,77 & Agree \\
\hline $\begin{array}{l}\text { The process of shipping goods } \\
\text { from department to } \\
\text { department is very good }\end{array}$ & 0 & 1 & 21 & 6 & 2 & 81 & 150 & 54 & 2,7 & $\begin{array}{l}\text { Quite } \\
\text { Agree }\end{array}$ \\
\hline TOTAL & 7 & 65 & 34 & 10 & 4 & 421 & 600 & 280,66 & 14,04 & \\
\hline
\end{tabular}

Overall in table 3 , a total score of 421 and an ideal score of 600 is obtained, so that a percentage of $70.17 \%$ is obtained, from the measurements as follows:

Maximum Index Value

$=5 \times 4 \times 30=600$

Minimum Index Value

$=1 \times 4 \times 30=120$

Interval Distance

$=($ max value - min value $): 5$

$=(600-120): 5=96$

Percentage score

$=[($ total score $):$ max value $] \times 100 \%$

$=(421: 600) \times 100 \%$

$=70.17 \%$

The percentage value obtained at $70.7 \%$, refers to the assessment criteria included in the agreed category. Therefore, it can be seen that the Effectiveness of Production at PT. Bintang Usaha Nasional is considered good.

Judging from the results of descriptive data processing on the Layout of Production Spaces, employees in the production section gave their responses on the Layout of Spatial Production that was applied to be in a good category, but some employees felt uncomfortable with the application of the Spatial Layout in the company. Layout applied by this PT.
Bintang Usaha Nasional covers elements of valuation which include products produced, production sequence, space requirements, equipment, and maintenance, the balance of capacity, placement, product flow, employee area, service area, and waiting area. By using a questionnaire measuring tool distributed to employees of the production department, it can be seen a description of the layout of the production space applied by the company is considered good in providing comfort to its employees in conducting production activities. Reviewed in a descriptive study of machine maintenance at PT. Bintang Usaha Nasional, employees of the production department gave their responses about the machine maintenance activities in the company which was considered good, but some employees did not agree with the maintenance carried out by the company. Machine Maintenance conducted by this PT. Bintang Usaha Nasional meets the elements of assessment which include the prevention and maintenance of damage. With the questionnaire measuring instrument, it can be concluded that the Machine Maintenance applied at PT. Bintang Usaha Nasional went well.

From the results of descriptive data processing about Production Effectiveness at PT. Bintang Usaha 
Nasional, employees of the production department responded that the effectiveness of production at the company was considered good, but some employees did not agree with the effectiveness of production at the company. Effectiveness of production at this PT. Bintang Usaha Nasional meets the elements of research which include production quantity and production quality. In the picture obtained from the results of the questionnaire, the effectiveness of production at PT. Bintang Usaha Nasional is going well.

\section{Verification Analysis}

This analysis uses the statistical method of path analysis. The first step that will be taken is to calculate the correlation coefficient. The correlation coefficient between the variables is calculated using the Pearson productmoment correlation formula and using the help of the SPSS v25 application with the following results:

Table 4. Correlations between research variables

\begin{tabular}{|c|c|c|c|c|}
\hline \multicolumn{5}{|c|}{ Correlations } \\
\hline & & $\mathrm{X} 1$ & $\mathrm{X} 2$ & $Y$ \\
\hline \multirow[t]{3}{*}{$\mathrm{X} 1$} & Pearson Correlation & 1 & ,074 & ,209 \\
\hline & Sig. (2-tailed) & & 696 & ,268 \\
\hline & $\mathrm{N}$ & 30 & 30 & 30 \\
\hline \multirow[t]{3}{*}{$\mathrm{X} 2$} & Pearson Correlation & 074 & 1 &, $915^{\star \star}$ \\
\hline & Sig. (2-tailed) & ,696 & &, 000 \\
\hline & $\mathrm{N}$ & 30 & 30 & 30 \\
\hline \multirow[t]{3}{*}{ Y } & Pearson Correlation & ,209 &, $915^{\star *}$ & 1 \\
\hline & Sig. (2-tailed) & ,268 &, 000 & \\
\hline & $\mathrm{N}$ & 30 & 30 & 30 \\
\hline **. & elation is significant a & 0.01 leve & 2-tailed) & \\
\hline
\end{tabular}

The table above can explain the correlation between variables, which can be concluded as follows:

1. The correlation value between the Production Room Layout (X1) and Machine Maintenance (X2) is 0.074. In the Interpretation guidelines, the correlation coefficient is included in the very low category.

2. The correlation value between the Production Room Layout (X1) and Production Effectiveness $(Y)$ is 0.209. In the guidelines for interpretation of the correlation coefficient included in the low category.

3. The correlation value between Machine Maintenance (X2) and Production Effectiveness $(Y)$ is 0.915. In the interpretation guide, the correlation coefficient is included in a very strong category.

Since the correlation coefficient for each variable has been obtained, it will then be calculated using path analysis with the following calculation. 
Table 5. Path coefficients

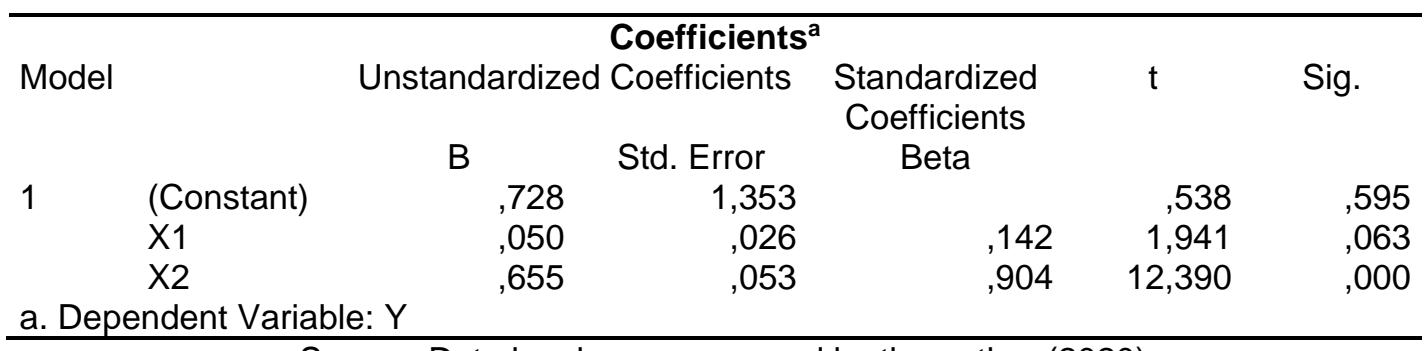

Source: Data has been processed by the author (2020)

From the results of the table, it can be seen that the $\mathrm{X} 1$ variable has a path coefficient of 0.142 or $14.2 \%$, and for the X2 variable of 0.904 or $90.04 \%$. The statement can be calculated as follows:

\section{Direct Influence}

$$
\begin{aligned}
& =\left(P_{Y X 1}\right)^{2} \\
& =(0,142)^{2} \\
& =0,0202 / 2,02 \%
\end{aligned}
$$

\section{Indirect influence}

$=$ PYX1 $X_{r \times 1 \times 2} \times P Y X 2$

$=(0.142)(0.074)(0.904)$

$=0.0095 / 0,95 \%$

\section{The effect of $X 2$ to $Y$ in total}

$=(P Y X 1)^{2}+\left(P Y X 1 X_{r \times 1 \times 2} \times P Y X 2\right)$

$=0,0202+0,0095$

$=0,0297 / 2,97 \%$

From these results, it can be seen that the magnitude of the influence of Production Room Layout (X1) which directly determines Production Effectiveness ( $\mathrm{Y}$ ) of $2.02 \%$ and an indirect effect through the relationship with Machine Maintenance (X2) of $0.95 \%$. Effect of Layout Production Room (X1) on Production Effectiveness (Y) of $2.97 \%$. This shows that the Production Room Layout (X1) affects the Effectiveness of Production ( $Y$ ).

\section{Direct Influence}

$$
\begin{aligned}
& =\left(P_{Y X 1}\right)^{2} \\
& =(0,904)^{2} \\
& =0,817 / 81,7 \%
\end{aligned}
$$

\section{Indirect influence}

$$
\begin{aligned}
& =P Y X 1 X_{r \times 1 \times 2} \times P Y X 2 \\
& =(0.904)(0.074)(0.142)
\end{aligned}
$$

$$
=0.0095 / 0,95 \%
$$

$$
\begin{aligned}
& \text { The effect of } \mathbf{X} 1 \text { to } Y \text { in total }= \\
& (P Y X 1)^{2}+\left(P Y X 1 X_{r \times 1 \times 2} \times P Y X 2\right) \\
& =0,817+0,0095 \\
& =0,8265 / 82,65 \%
\end{aligned}
$$

From the results of these data, it can be seen the magnitude of the influence of Machine Maintenance (X2) which directly determines the Effectiveness of Production ( $\mathrm{Y}$ ) of $81.7 \%$, and the indirect effect through the relationship with the Production Room Layout (X1) of $0.95 \%$. The Effect of Machine Maintenance (X2) on Production Effectiveness $(Y)$ of $82.65 \%$. This shows that Machine Maintenance has a significant effect on Production Effectiveness.

\section{Hypothesis testing}

The hypotheses to be tested in this study are as follows: (1) The Production Room Layout at PT. Bintang Usaha Nasional has not been well structured; (2) Production Machine Maintenance at PT. Bintang Usaha Nasional has not gone well; (3) Production Effectiveness at PT. Bintang Usaha Nasional has not gone well. (4) Production Room Layout Affects Production Effectiveness in PT. Bintang Usaha Nasional. (5) Production Machine Maintenance Influences Production Effectiveness in PT. Bintang Usaha Nasional. (6) Production Room Layout and Production Machine Maintenance 
Affect Production Effectiveness di PT. effect on Production Bintang Usaha Nasional.

To find out and prove the influence of Layout of Production Room and Machine Maintenance partially and simultaneously, a hypothesis test is therefore carried out, which is as follows:

$\begin{array}{ll}\mathrm{H} 0: \mathrm{PYX} 1=0 & \text { Layout of Production } \\ & \text { Room has no } \\ & \text { significant effect on } \\ & \text { Production } \\ & \text { Effectiveness. } \\ \mathrm{H} 1: \mathrm{PYX} 1 \neq 0 \quad & \text { Layout of Production } \\ & \text { Room has a significant }\end{array}$

Effectiveness.

H0: $P Y X 2=0 \quad$ Machine Maintenance does not significantly influence Production Effectiveness.

$\mathrm{H} 1 ; \mathrm{PYX} 2 \neq 0 \quad$ Machine Maintenance has a significant effect on Effectiveness. Production

From the criteria above, the test results will be obtained following the table below:

Table 6. Partial Testing of Effect of Production Room Layout and Production Machine Maintenance on Production Effectiveness

\begin{tabular}{cccccc}
\hline Structural Path coefficient & t-value & t-table & P-value & \multicolumn{1}{c}{ Conclusions } \\
\hline Pyx1 & 0,142 & 1,941 & 1,70 & 0,00 & $\begin{array}{l}\mathrm{H} 1 \text { is accepted, there is an } \\
\text { influence between } \mathrm{X} 1 \text { and } \mathrm{Y} .\end{array}$ \\
Pyx2 & 0,904 & 12,390 & 1,70 & 0,00 & $\begin{array}{l}\mathrm{H} 1 \text { accepted, the influence of } \\
\mathrm{X} 2 \text { and Y. }\end{array}$ \\
\hline
\end{tabular}

Source: Data has been processed by the author (2020)

From the table above it can be seen that the $X 1$ count is 1,941 and $X 2$ is 12,390 . Table value of 1.70 is obtained from the calculation $(n-k)=30$ $-3=27$ with a significance level $(\alpha) 0.05$. Then the decision is:

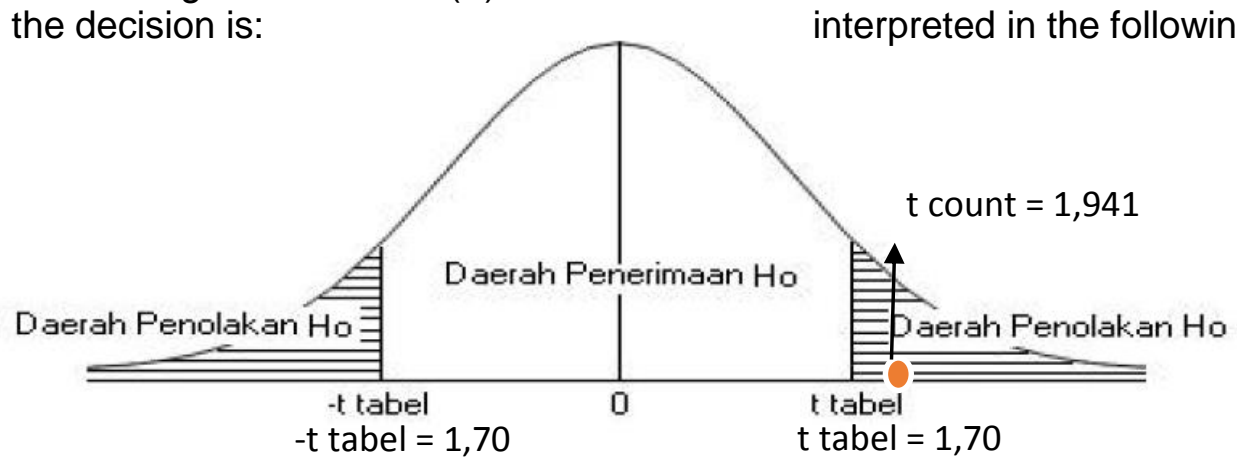

Figure 1. $P_{Y x 1}$ t-test curve

Source: Data has been processed by the author (2020)

Based on the picture above, it can be concluded that according to the test criteria, if $t_{\text {count }}>t_{\text {table, }}$, then $H_{0}$ is in the area of observation, meaning $\mathrm{H}_{1}$ is accepted. 
2. $t_{\text {count }} \mathrm{X} 2$ of 12.390 which is greater

that the significance is significant than ttable is 1.70 which means

between $\mathrm{X} 2$ and $\mathrm{Y}$.

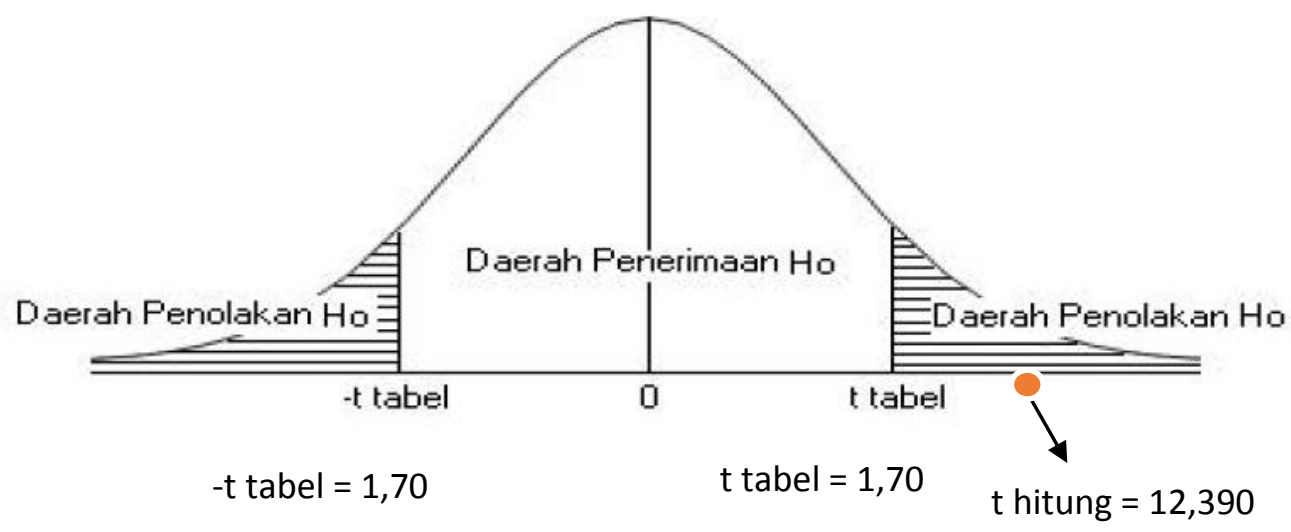

Figure 2. $P_{y_{X 2}}$ t-test curve

Source: Data has been processed by the author (2020)

From the picture above, it can be concluded that according to testing if $t_{\text {count }}>t_{\text {table }}$ then $H_{0}$ is in the rejection area, meaning $\mathrm{H}_{1}$ can be accepted.

In proving whether the Layout of Production Room and Machine Maintenance affect the Effectiveness of Production, then testing the hypothesis with the formula as follows:

$\mathrm{H}_{0}: \mathrm{P}_{Y X_{1}}=\mathrm{P}_{\mathrm{YX} 2}=0$ Simultaneously, The Production Room Layout and Production Machine Maintenance no effect significant to Production effectiveness.
H0: ${ }_{\mathrm{PYX} 1} \neq \mathrm{P}_{\mathrm{YX} 2} \neq 0$ Simultaneously, The Production Room Layout and Production Machine Maintenance Influential effect significant to Production effectiveness.

$F_{\text {count }}$ and $F_{\text {table }}$ selection results with preferences:

If $F_{\text {count }}>F_{\text {table, }}$, then $\mathrm{HO}$ is rejected at alpha $5 \%$.

If $\mathrm{F}_{\text {count }}<\mathrm{f}_{\text {tabel, }}$, then $\mathrm{HO}$ is accepted at alpha $5 \%$.

Table 7. Simultaneous Hypothesis Testing

\begin{tabular}{|c|c|c|c|c|}
\hline \multicolumn{5}{|c|}{ ANOVA $^{a}$} \\
\hline Model & Sum of Squares $\mathrm{df}$ & Mean Square & $\mathrm{F}$ & Sig. \\
\hline $\begin{array}{ll}1 & \text { Regression } \\
\text { Residual } \\
\text { Total }\end{array}$ & $\begin{array}{r}107,090 \\
17,87627 \\
124,967\end{array}$ & $\begin{array}{r}53,545 \\
, 662\end{array}$ & 80,874 &, $000^{\mathrm{b}}$ \\
\hline
\end{tabular}

a. Dependent Variable: $Y$

b. Predictors: (Constant), X2, X1

Source: Data has been processed by the author (2020)

Based on the table above, it can be seen that the results of $F_{\text {count }}$ are 80.874 and the level of alpha $(\alpha)$ is 0.05 with $\mathrm{df} 1=3-1=2$, and $\mathrm{df} 2=30-2=28$, the known Ftable value is 3.34 . Therefore it can be concluded that the value of $F_{\text {count }}(80,874)$ is greater than the value of $F_{\text {table }}$ (3.34) with a significance value of 0,000 , which means $\mathrm{H}_{1}$ is accepted and there is a significant influence of production space 
layout and machine maintenance on production effectiveness.
Next below is the result of the coefficient of determination seen in table 8 as follows:

Table 8. Coefficient of Determination

\begin{tabular}{cc|c|c|c}
\hline Model & $\mathrm{R}$ & $\mathrm{R}$ Square & $\begin{array}{c}\text { Model Summary } \\
\text { Adjusted R Square }\end{array}$ & Std. Error of the Estimate \\
\hline 1 &, $926^{\mathrm{a}}$ &, 857 &, 846 &, 814 \\
\hline a. Predictors: (Constant), X2, X1 & \\
Source: Data has been processed by the author (2020)
\end{tabular}

The value of $R$ Square in the table above can be calculated using this formula:

$$
\begin{aligned}
\text { rYE } & =\sqrt{\left(1-R^{2} y x_{1 \ldots x_{n}}\right)} \\
& =\sqrt{(1-0,857)}=\mathbf{0 , 1 4 3}
\end{aligned}
$$

This can be interpreted that the Layout of Production Room and Machine Maintenance of Production Effectiveness at PT. Bintang Usaha Nasional is 0.857 ( $R$ Square) and is influenced by other factors not examined (epsilon) of 0.143 .

Based on the results of the verification analysis obtained using SPSS v25 that, the Production Space Layout variable (X1) influences Production Effectiveness (Y). The results showed that the influence between the Production Room Layout and Machine Maintenance on Production Effectiveness, this was evidenced by the t-test statistic for the Production Space Layout variable with a $t_{\text {count }}$ greater than $t_{\text {table, }}$, which means that there was an influence between $\mathrm{X} 1$ and $\mathrm{Y}$. Thus it was concluded that this study succeeded in proving the fourth hypothesis, namely the Production Spatial Layout influences the effectiveness of production.

Based on the analysis results obtained through calculations using SPSS v25 that the variable Machine Maintenance (X2) influences Production Effectiveness $(Y)$. The results showed that the influence between Production Room Layout and Machine Maintenance on Production Effectiveness, this was proven by t-test statistics for Machine Maintenance variables with $t_{\text {count }}$ greater than $t_{\text {table, }}$ which means that the influence of $\mathrm{X} 2$ and $\mathrm{Y}$. Thus it can be concluded that the researchers succeeded in proving the fifth hypothesis that Machine Maintenance influences the effectiveness of production.

From the results of the analysis of previous calculations, it can be seen that there is a relationship between variables $\mathrm{X} 1$ and $\mathrm{X} 2$ expressed correlation. While based on $\mathrm{R}$ Square contained in the previous table that is equal to 0.857 . This shows that the contribution of the influence of $X 1$ and $X 2$ to $Y$ is $85.7 \%$, while the remainder is the contribution of other variables. The results of this study indicate that there is an influence between the Production Room Layout and Machine Maintenance of Production Effectiveness. Can be proven by the results of the F-test statistic with a $F_{\text {count }}$ greater than $F_{\text {table. }}$ These results state that $X 1$ and $X 2$ affect $Y$ and each variable affects each other. This research succeeded in showing that the last hypothesis is the Production Room Layout and Machine Maintenance affect the Effectiveness of Production at PT. Bintang Usaha Nasional.

\section{CONCLUSION}

From the results of research and discussion, it can be drawn several conclusions, namely employee responses about the Layout of the Production Room at The PT. Bintang Usaha Nasional obtained from the 
results of the descriptive analysis states that the Production Space Layout variable is in a good category. Indicators are very prominent in the Layout variable that the results and the quality of the products produced are following the target, while the indicators considered lacking are the layout of the machines which are considered not following the order of production. Meanwhile, the employees' responses regarding Machine Maintenance implemented at The PT. Bintang Usaha Nasional obtained from the descriptive analysis results stated that the Machine Maintenance variable was in a good category, with the most prominent indicator being that the application of engine maintenance went well. But as for those who are considered lacking, one of which is the maintenance of the machine directly after damage.

$$
\text { Employee responses on }
$$

Production Effectiveness at PT. Bintang Usaha Nasional obtained from descriptive analysis results state that the Production Effectiveness variable is in a good category. The most prominent indicator is that defective products can be minimized properly. But there are still lacks, one of which is where the process of sending goods from department to other departments takes place less well.

\section{REFERENCES}

Anggraini, M. (2016). Pengaruh Pemeliharaan mesin terhadap kualitas sepatu pada PT. Nikomas Gemilang. Jurnal Manajemen.

Assauri, S. (2016). Manajemen operasi produksi pencapaian sasaran organisasi berkseinambungan, Edisi 3. Jakarta: Rajawali Pers.

Handoko, H. (2014). Dasar-dasar Manajemen Produksi dan Operasi. Jakarta: BPFE.

Laksanawati, E. K. (2016). Analisis Tata Letak Material di gudang PT. GGS dalam meningkatkan efektivitas kerja. Jurnal Teknik, 12-16.

Priansa, D. J. (2015). Manajemen Perkantoran. Bandung: Alfabeta.

Ravianto J. (2014). Produktivitas dan Pengukuran. Jakarta: Binaman Aksara.

Rusdiana. (2014). Manajemen Operasi. Bandung: Pustaka Setia.

Sugiarto. (2017). Metode Penelitian Bisnis. Yogyakarta: Andi. 